\title{
NILAI RELIGIUS DALAM NOVEL RANIA LANTUNAN CINTA DI SEPERTIGA MALAM KARYA ERIA CHUZAIMIAH DAN NASRULLAH
}

\author{
Sujoko $^{1}$, Listiana $^{2}$ \\ Program Studi Pendidikan Bahasa dan Sastra Indonesia, \\ Fakultas Keguruan dan Ilmu Pendidikan, Universitas Batanghari, \\ Jambi \\ sujoko@unbari.ac.id \\ listyana057@gmail.com
}

\begin{abstract}
The purpose of this research is to describe the religious values related to the relationship between human and God, relationship of human to humans, and the relationship between human and nature in the novel Rania Lantunan Cinta Di Sepertiga Malam by Eria Chuzaimiah and Nasrullah. This research is descriptive qualitative. The data collection technique used in this research is documentation study. In analyzing the data, content analysis technique is used. The results of this study consisted of 164 expressions. The religious value of the relationship between human and God includes the following five aspects: 1) there are 36 expressions of believing in Allah;2) there are 44 expressions of wroshipping Allah; 3) there are 49 expressions of being grateful for His blessings; 4) there is one expression of being patient with His trials; 5) there are nine expressions of asking for forgiveness. The religious value of human to human relation includes 4 aspects, as follows: 1) there is one expression of fairness, 2) 10 expressions of helping each other, 3) eight expressions of forgiveness; and 4) five expressions of keeping promises. The religious value of the relationship between human and nature includes one aspect which only occures one time namely preserving the environment.
\end{abstract}

Keywords: value, religious, novel

${ }^{1}$ Dosen Program Studi Pendidikan Bahasa dan Sastra Indonesia, Fakultas Keguruan dan Ilmu Pendidikan, Universitas Batanghari, Jambi

${ }^{2}$ Mahasiswa Program Studi Pendidikan Bahasa dan Sastra Indonesia, Fakultas Keguruan dan Ilmu Pendidikan, Universitas Batanghari, Jambi

Nilai Religius dalam Novel Rania Lantunan Cinta di Sepertiga Malam Karya Eria Chuzaimiah dan Nasrullah 


\section{PENDAHULUAN}

Sastra merupakan gambaran kehidupan yang disajikan secara luas dan mendalam. Sastra dapat mewakili persoalan-persoalan masyarakat tertentu yang memiliki pengaruh terhadap tematema yang diangkat dalam karya-karya tersebut. Sastra juga merupakan lembaga sosial yang menggunakan bahasa sebagai medium. Bahasa itu sendiri merupakan ciptaan sosial. Sastra menampilkan gambaran kehidupan, dan kehidupan itu sendiri adalah suatu kenyataan sosial.

Rokhmansyah,

(2014:8)

mengatakan "Karya sastra dapat dijadikan tuntunan dalam menjalani hidup yang dapat menumbuhkembangkan nilai-nilai dalam kehidupan manusia". Karya sastra suatu wujud gagasan seseorang melalui pandangan terhadap lingkungan sosial yang berada di sekelilingnya. Karya sastra merupakan sebuah karya yang kreatif yang diciptakan dengan ide-ide yang cemerlang. Karya sastra lahir dari tangantangan hebat pengarang. Karya sastra dapat diciptakan dari kisah nyata baik yang dialami oleh pengarang sendiri maupun oleh orang lain. Karya sastra sangat penting bagi kehidupan manusia, selain itu karya sastra banyak menghasilkan nilai-nilai yang mengandung ajaran agama yang dapat diteladani bagi pembaca. Karya sastra juga merupakan karya seni yang diciptakan seorang sastrawan yang mengandung unsur keindahan untuk dinikmati masyarakat, bukan hanya sekedar dibaca karya sastra juga dapat kita gunakan sebagai media pembelajaran sastra di sekolah.

Uraian tersebut mendasari penelitian ini dilakukan dengan karya sastra sebagai objek kajian. Pada pembelajaran karya sastra dapat diperoleh informasi sastra terdiri dari tiga jenis di antaranya puisi, prosa, dan drama. Prosa sebagai karya sastra yang memiliki jenis diantaranya novel. Novel salah satu karya sastra yang menceritakan tentang kehidupan masyarakat dan novel juga banyak diminati ataupun disukai oleh masyarakat. Hal ini dapat dilihat di toko buku novel yang banyak dicari oleh pembaca. Novel bisa dibaca semua kalangan masyarakat baik dewasa, remaja, maupun orang tua. Saat kita membaca novel pasti kita akan merasakan seolah-olah kita yang berada di dalam novel tersebut, karena novel pada umumnya mengisahkan kehidupan manusia sehingga seseorang yang membacanya akan terbawa alur cerita novel.

Menurut Kosasih (2008:4-5), "Novel memiliki berbagai manfaat bagi pembaca". Selain dapat menghibur novel juga dapat dijadikan renungan oleh pembaca. Pengalaman-pengalaman cerita novel dapat memberikan motivasi bagi pembaca dalam kehidupannya. Novel dapat dijadikan teladan serta tuntunan hidup bagi pembaca. Membaca novel dapat memberikan inspirasi bagi pembaca. Selain itu, novel juga dapat menambah wawasan pengetahuan serta dapat mengubah pola pikir manusia menjadi lebih baik dan dapat membangun iman serta karakter bagi pembaca. Berdasarkan pendapat di atas, diketahui bahwa novel sangat bermanfaat bagi pembaca terutama sebagai tuntunan. Di dalam novel terdapat nilai-nilai yang bisa kita kaji.

Nilai merupakan pandangan objektif seseorang atas dasar perilaku yang disesuaikan dalam keadaan-keadaan dalam keseharian, perilaku ini dianggap memiliki kegunaan, kebermanfaatan, dan juga keberhargaan bagi diri sendiri atau orang lain. Ada beberapa macam nilai yang dapat dikaji di dalam novel yaitu nilai moral, nilai sosial, nilai religius, nilai budaya, nilai pendidikan, nilai etika, 
nilai estetika, nilai politik, nilai patriotik, nilai psikologi, nilai ekonomi, dan nilai historis. Di antara beberapa nilai yang terdapat dalam novel tersebut, nilai religious menjadi fokus dalam penelitian ini.

Nilai religius dalam suatu karya sastra sangat diperlukan. Karena nilai religius salah satu nilai yang berhubungan dengan agama, salah satunya seperti agama Islam. Seperti zaman globalisasi yang kita lihat saat ini sudah mulai bergesernya nilai religius di tengah masyarakat. Sebagai contoh menipisnya perilaku sosial yang terjadi pada masyarakat, contohnya dilingkungan masyarakat seseorang meminjamkan barang kepada orang lain sudah jarang terjadi lagi. Adapun contoh di media sosial seorang oknum polisi ini ludahi pengemudi mobi yang disetopnya! Semua itu terjadi akibat suburnya sikap individualisme di kalangan masyarakat. Remaja sekarang juga banyak yang menganut gaya hidup hedonis, yang membuat remaja kini hanya berpikir tentang kesenangan diri sendiri tanpa memikirkan orang lain, itu semua karena rendahnya keimanan, kesabaran, dan rasa syukur pada setiap individu. Seseorang melakukan segala cara untuk bisa mencapai tujuan yang diinginkan tanpa memikirkan dampaknya seperti apa pada orang lain.

Salah satu novel yang mengedepankan nilai religius khususnya agama islam adalah novel Rania Lantunan Cinta di Sepertiga Malam karya Eria Chuzaimiah dan Nasrullah, diterbitkan oleh KMO Indonesia, pada tahun 2019 cetakan kedua dengan jumlah halaman 284 memiliki ukuran 14 x 20,5 $\mathrm{cm}$. Novel Rania Lantunan Cinta di Sepertiga Malam karya Eria Chuzaimiah dan Nasrullah memiliki sampul yang menarik berwarna warni ada biru, merah jambu, kuning dan ada gambar wanita duduk di atas rerumputan, dengan sampul yang begitu anggun dengan judul yang ditulisnya membuat pembaca semakin penasaran dengan ceritanya.

Novel Rania Lantunan Cinta di Sepertiga Malam mengandung nilai-nilai religius di dalamnya. Nilai-nilai religius inilah yang dapat membuat novel ini banyak diminati. Nilai-nilai seperti ini yang dikaji dalam penelitian ini. Dari uraian tersebut maka penelitian tentang nilai religius ini dilakukan karena nilai religius sangat berperan penting bagi kehidupan masyarakat.

\section{METODE PENELITIAN}

"Jenis penelitian berarti cara yang dipergunakan seorang peneliti di dalam usaha memecahkan masalah yang diteliti (Siswantoro, 2010:55)". Jenis penelitian ini adalah deskriptif yang bersifat kualitatif. "Deskriptif merupakan penelitian yang dimaksudkan untuk menjelaskan fonemena atau karakteristik individual, situasi, atau kelompok tertentu secara akurat (Danim, 2002:41)".

Penelitian deskriptif kualitatif adalah penelitian yang cenderung menggunakan analisis dan menjelaskan fenomena atau karakteristik individual, situasi atau kelompok secara akurat. Penelitian ini menggambarkan tentang objek yang diteliti atau data yang dianalisis dengan menggunakan kata-kata yang sesuai dengan keberadaan yang ada. Penelitian ini menggambarkan nilai-nilai religius yang berkaitan dengan hubungan manusia dengan Tuhan, hubungan manusia dengan manusia, dan hubungan manusia dengan alam dalam novel Rania Lantunan Cinta di Sepertiga Malam Karya Eria Chuzaimiah dan Nasrullah.

Teknik pengumpulan data yang digunakan dalam penelitian ini adalah teknik dokumentasi. "Teknik pengumpulan data merupakan langkah yang paling utama dalam penelitian, 
karena tujuan utama dari penelitian adalah mendapatkan data (Sugiyono, 2007:308)".

"Analisis data merupakan suatu proses mengatur urutan data, mengorganisasikannya ke dalam suatu pola, kategori, dan satuan uraian dasar (Patton dalam Muhammad 2011:221)". Adapun analisis data dalam penelitian ini dilakukan dengen analisis isi.

\section{HASIL DAN PEMBAHASAN}

Berdasarkan hasil penelitian yang telah dilakukan, diketahui hal-hal sebagai bewrikut. 1) Nilai religius sebanyak 164 ungkapan yang terdiri atas nilai religius hubungan manusia dengan Allah sebanyak 5 aspek, hubungan manusia dengan manusia ebanyak 4 empat aspek dan hubungan manusia dengan alam sebanyak 1 aspek. 2) Nilai religius hubungan manusia dengan Allah ditemukan sebanyak 139 ungkapan yang terdiri atas lima aspek, yaitu: aspek mensyukuri nikmat-Nya ditemukan 49 ungkapan; aspek beribadah kepada-Nya ditemukan 44 ungkapan, dan aspek bersabar menerima cobaan-Nya ditemukan 1 ungkapan. 3) Nilai religius hubungan manusia dengan manusia ditemukan sebanyak 24 ungkapan yang terdiri dari empat aspek, yaitu aspek tolong menolong ditemukan 10 ungkapan, aspek pemaaf ditemukan 8 ungkapan, dan aspek adil ditemukan 1 ungkapan. 4) Nilai religius hubungan manusia dengan alam ditemukan sebanyak 1 ungkapan yang terdiri dari satu aspek.

\section{Analisis Nilai Religius Hubungan Manusia dengan Allah \\ a. Aspek Beriman kepada Allah}

Aspek beriman kepada Allah yaitu, "Hubungan dengan Allah dalam arti perhambaan terhadap-Nya merupakan titik tolak terwujudnya ketakwaan. Seorang yang bertakwa adalah orang yang menghambakan dirinya kepada Allah dan selalu menjaga hubungan dengan-Nya setiap saat (Kozin, 2013:108)". Seseorang yang selalu menyembah Allah dan selalu memenuhi perintanya merupakan orang yang selalu taat kepada-Nya. Ungkapan yang berkaitan dengan aspek beriman kepada Allah terdapat 36 ungkapan diantaranya, sebagai berikut.

Kutipan 1

"Kamar yang diperuntukkan untuk empat orang ini tidak berpendingin udara atau kipas angin tetapi Masya Allah, dinginya menusuk tulang"(RLCSM, 2019:2)

Pada kutipan 1 terdapat nilai religius hubungan manusia dengan Allah aspek beriman kepada Allah. Pada kutipan 1 dapat dianalisis bahwa dalam kalimat tersebut terdapat nilai religius Masya Allah. Ungkapan tersebut termasuk salah satu nilai religius hubungan manusia dengan Allah aspek beriman kepada Allah. Karena pada kalimat tersebut menjelaskan bahwa Masya Allah adalah salah satu bentuk ungkapan yang sering diucapkan seorang muslim untuk menunjukkan kekaguman terhadap seseorang, sesuatu atau kejadian. Maka dari itu masya Allah termasuk aspek beriman kepada Allah karena termasuk perhambaan atau ketakwaan seorang muslim kepada Allah, Hal ini sesuai dengan pendapat Khozin, (2013:108).

\section{b. Aspek Beribadah Kepada-Nya}

Beribadah kepada-Nya yaitu dengan jalan melaksanakan shalat lima kali sehari semalam. Hubungan dengan Allah dimulai dengan melaksanakan tugas perhambaan dengan melaksanakan ibadah secara sunguh-sungguh (khusyuk) dan ikhlas seperti mendirikan shalat dengan khusyuk (Kozin, 2013:108-109). Ungkapan yang berkaitan dengan 
beribadah kepada-Nya terdapat 48 ungkapan diantaranya, sebagai berikut.

Kutipan 2

"Di kaki ardi, beberapa bangunan menjadi saksi kisah cinta di penghujung malam. Rania tak pernah menyangka, ini akan menjadi malam terindah yang merangkai semua cerita. Cinta kepada Rabb-Nya, dan cinta pada seorang makhluk ciptaan-Nya" (RLCSM, 2019:1)

Pada kutipan 2 terdapat nilai religius hubungan manusia dengan Allah aspek beribadah kepada-Nya. Berdasarkan ungkapan tersebut dapat dianalisis bahwa dalam Rania tak pernah menyangka, ini akan menjadi malam terindah yang merangkai semua cerita. Cinta kepada Rabb-Nya, terdapat nilai religius beribadah kepadaNya. Kalimat tersebut termasuk salah satu nilai religius hubungan manusia dengan Allah aspek beribadah kepadaNya. Karena pada kalimat tersebut menjelaskan bahwa Rania melaksanakan sholat Tahajjud di sepertiga malam dengan perasaan tenang, damai, dan hanya di temani oleh beberapa bangunan yang menjadi saksi kisah di penghujung malamnya. Hal tersebut bisa di jadikan contoh dalam kehidupan sehari-hari agar kita rajin melaksanakan sholat Tahajjud, Hal ini sesuai dengan pendapat Khozin ( 2013:108-109).

\section{c. Aspek Mensyukuri Nikmat-Nya}

Bersyukur merupakan ungkapan rasa terimakasih kepada Allah atas karunia-Nya dan selalu mensyukuri apapun yang telah diberikan Allah kepada kita "Mensyukuri nikmat-Nya dengan jalan menerima, mengurus, memanfaatkan semua pemberian Allah kepada manusia (Kozin, 2013:111)". Ungkapan yang berkaitan dengan mensyukuri nikmat-Nya terdapat 50 ungkapan diantaranya, sebagai berikut. Kutipan 3
"Ketika menginjakkan kaki di aula, Rania merasa lebih hangat, Alhamdullilah" (RLCSM, 2019:5)

Pada kutipan 3 terdapat nilai religius hubungan manusia dengan Allah dalam aspek mensyukuri nikmat-Nya. Berdasarkan ungkapan 3 dapat dianalisis bahwa dalam kalimat tersebut terdapat nilai religius mensyukuri Nikmat-Nya, dengan kata Alhamdullilah. Ungkapan tersebuat termasuk salah satu nilai religius hubungan manusia dengan Allah aspek mensyukuri nikmat-nya karena pada kalimat tersebut menjelaskan bahwa Alhamdullilah adalah salah satu bentuk rasa syukur kepada Allah karena diberikan nikmat ketenangan jiwa saat berada di suatu tempat (segala puji hanya milik Allah). Kalimat tersebut menjelaskan bahwa Rania merasa lebih hangat ketika mengijakkan kaki ke dalam aula (masjid), Hal ini sesuai dengan pendapat (Khozin, 2013:111).

\section{d. Aspek Bersabar Menerima Cobaan- Nya}

Bersabar menerima cobaan-Nya yaitu menerima dengan ikhlas dan tabah dengan apa yang telaah diberikan oleh Allah. "Bersabar menerima cobaan Allah dalam makna tabah, tidak putus asa ketika mendapat musibah atau menerima bencana (Kozin., 2013:111)". Ungkapan yang berkaitan dengan aspek bersabar menerima cobaanya terdapat 5 ungkapan diantaranya, sebagai berikut.

Kutipan 4

Ustadz Lukman mengangguk. "Ya udah. Antun tunggu aja. Kalau sudah dapat akhwatnya, nantii ana kabarin". "Jazakallah khair, bang".

“Wayyaakum”. Semenjak hari itu, hanif belum menerima satu biodata akhwat pun dari ustadz-nya. Allah belum ngasih (RLCSM, 2019:176).

Pada kutipan 4 terdapat nilai religius hubungan manusia dengan Allah 
dalam aspek bersabar menerima cobaanNya. Berdasarkan ungkapan tersebut dapat dianalisis bahwa dalam kalimat tersebut terdapat nilai religius bersabar menerima cobaan-Nya. Semenjak hari itu, hanif belum menerima satu biodata akhwat pun dari ustadz-nya. Allah belum ngasih. Ungkapan tersebuat termasuk salah satu nilai religius hubungan manusia dengan Allah aspek bersabar menerima cobaan-Nya karena pada kalimat tersebut menjelaskan bahwa Allah ingin menguji hamba-Nya dengan ujian mendatangkan jodohnya dalam waktu yang lama karna pada dasar nya Allah akan mempertemukan nya di waktu yang tepat, Hal ini sesuai dengan pendapat Khozin (2013:111).

\section{e. Aspek Memohon Ampun}

Memohon ampun kepada tuhan merupakan memohon kepada tuhan agar diampuni dosa-dosanya serta dijauhkan dari larangn-larangan-Nya atau hal-hal yang tidak baik. "Memohon ampun atas segala dosa, dan tobat dalam makna sadar atau tidak lagi melakukan segala perbuatan jahat atau tercela (Khozin, 2013:111). Ungkapan yang berkaitan dengan memohon ampun terdapat 9 ungkapan diantaranya, sebagai berikut.

Kutipan 5

"Ia mengingat betapa diri belum menjadi hamba yang bersyukur. Begitu banyak nikmat yang Allah berikan kepadanya, namun begitu sedikit balasan yang ia serahkan. Astagfirullah. Ampuni hamba, ya Allah,tangisnya dalam hati" (RLCSM, 2019:7).

Pada kutipan 5 terdapat nilai religius hubungan manusia dengan Allah dalam aspek mohon ampun. Berdasarkan ungkapan 5 dapat dianalisis bahwa dalam kalimat tersebut terdapat nilai religius memohon ampun. Ampuni hamba, ya Allah. Ungkapan tersebuat termasuk salah satu nilai religius hubungan manusia dengan Allah aspek mohon ampun karena pada kalimat tersebut menjelaskan bahwa begitu lalainya kita menjadi seorang hamba yang tidak pandai bersyukur kepada Allah sesungguh nya Allah maha pengampun, Hal ini sesuai dengan pendapat Khozin (2013:111).

\section{Analisis Nilai Religius Hubungan Manusia dengan Manusia \\ a. Aspek Adil}

Adil merupakan seseorang yang tidak memihak kepada siapapun atau sama rata "Adil memiliki makna senantiasa mengedepankan standar adil, tanpa dipengaruhi sikap dan perasaan yang dimilikinya, ketika berhadapan dengan orang lain (Wibowo, 2014:81)". Ungkapan yang berkaitan dengan adil terdapat 1 ungkapan sebagai berikut.

Kutipan 6

"Ia ingin membuktikan bahwa semua bisa dilakukan asalkan adil dalam membagi waktu sesuai porsi. Lagi pula, dimana ada kemauan, pasti Allah tunjukkan jalan" (RLCSM, 2019:168).

Pada kutipan 6 terdapat nilai religius hubungan manusia dengan manusia dalam aspek adil. Berdasarkan ungkapan 6 dapat dianalisis bahwa dalam kalimat tersebut terdapat nilai religius aspek adil. Adil dalam membagi waktu sesuai porsi. Ungkapan tersebuat termasuk salah satu nilai religius hubungan manusia dengan manusia aspek adil karena pada kalimat tersebut menjelaskan bahwa Rania tidak meninggalkan salah satu tanggung jawannya ia bisa membagi waktunya untuk mengajar privat, liqo dan TPA. Sikap Rania yang adil dalam membagi waktu mengajar privat, liqo dan TPA, bisa di jadikan contoh dalam kehidupan sehari-hari bahwa kita dalam keadaan sesibuk apapun tidak boleh meninggalkan tanggung jawab kita, Hal 
ini sesuai dengan pendapat Wibowo (2014:81).

\section{b. Aspek Tolong Menolong}

Menolong sesama merupakan sikap dan tindakan yang selalu ingin memberi bantuan kepada orang lain dan masyarakat yang membutuhkan. Menurut Wibowo, (2014:84) "Tolong menolong adalah saling membantu antarsesama manusia. Dengan tolong menolong kita akan dapat menumpuk rasa kasih sayang antar tetangga, antar teman, antar rekan kerja”. Ungkapan yang berkaitan dengan aspek tolong menolong terdapat 12 ungkapan diantaranya sebagai berikut.

Kutipan 7

"Afwan.Ana tahu antum mungkin sedang istirahat. Ustadz Kamil tadi nelepon ana, beliau minta tolong kalau ada ikhwan yang bisa menjadi imam Tahajjud malam ini di masjid SMA 73," jelas Heri. "Ana langsung kefikiran antum". Hanif menarik nafas pelan. Raganya emang butuh istirahat, tetapi jiwaanya terpanggil untuk melaksanakan amanah. Tanpa pikir panjang ia menjawab, “Insyaallah" (RLCSM, 2019:18)

Pada kutipan 7 terdapat nilai religius hubungan manusia dengan manusia dalam aspek tolong menolong. Berdasarkan ungkapan 7 dapat dianalisis bahwa dalam kalimat tersebut terdapat nilai religius. beliau minta tolong kalau ada ikhwan yang bisa menjadi imam Tahajjud malam ini di masjid SMA 73," jelas Heri. Ungkapan tersebuat termasuk salah satu nilai religius hubungan manusia dengan manusia aspek tolong menolong karena pada kalimat tersebut menjelaskan bahwa Heri meminta bantuan kepada Hanif untuk menjadi imam tahajjud di masjid SMA 73, karena merasa jiwa nya terpanggil tanpa pikir panjang Hanif bersedia menjadi imam tahajjud prilaku hanif terdapat dalam kehidupan nyata sikap Hanif yang menerima amanah dari heri bisa di jadikan contoh dalam kehidupan di masyarakat, hal ini sesuai dengan pendapat Wibowo, (2014:84).

\section{c. Aspek Pemaaf}

"Pemaaf adalah sikap dan tindakan yang selalu berupaya mencegah terjadinya perselisishan antarsesama, dan mengembangkan upaya-upaya untuk memperbaiki keadaan yang sudah terjadi (Wibowo, 2014:84)". Memaafkan orang lain adalah nilai hidup yang universal sifatnya. Semua agama dan semua menilai hal tersebut tindakan yang terpuji. ungkapan yang berkaitan dengan pemaaf terdapat 12 ungkapan diantaranya, sebagai berikut.

Kutipan 8

Mereka meminta maaf. Umi sudah memaafkan, ini bukan sepenuhnya kesalahan mereka. Sudah menjadi ketetapan Allah "Lanjut Umi" (RLCSM, 2019:101).

Dalam ungkapan tersebut terdapat nilai religius hubungan manusia dengan manusia dalam aspek pemaaf. Berdasarkan ungkapan tersebut dapat dianalisis bahwa dalam kalimat tersebut terdapat nilai religius pemaaf. Mereka meminta maaf. Umi sudah memaafkan. Ungkapan tersebuat termasuk salah satu nilai religius hubungan manusia dengan manusia pada aspek pemaaf karena pada kalimat tersebut menjelaskan bahwa sikap umi memaafkan dua orang suami istri yang telah menabrak Hanif, umi berkata ini sudah menjadi ketetapan Allah jika Hanif mengalami kecelakaan, perilaku umi terdapat dalam kehidupan kita seharihari. Saling memaafkan dan memberi maaf adalah sifat yang sangat di senangi oleh Allah. Hal ini sesuai dengan pendapat Wibowo (2014:84). 


\section{d. Aspek Menepati Janji}

Seseorang yang memiliki watak dapat dipercaya berarti orang trsebut memiliki kejujuran, integritas, royalitas, reabilitas, dan dapat menepati janji (Wibowo, 2014:80). Seseorang yang menepati janji berarti dapat diberi amanah. Seseorang yang diberi amanah adalah dia yang dapat dipercaya. Orang yang amanah akan mampu tegak berdiri di atas prinsip tauhid dan mendorong dirinya untuk senantiasa konsisten dengan prinsip itu, dalam kondisi dan situasi apapun. Ungkapan yang berkaitan dengan menepati janji terdapat 5 ungkapan diantaranya, sebagai berikut. Kutipan 9

"Bagaimana, Rania?" tanya Nisa.

Hari ini ia mereka janjian mushallah kampus untuk bertemu (RLCSM, 2019:190).

Dalam ungkapan tersebut terdapat nilai religius hubungan manusia dengan manusia dalam aspek menepati janji. Berdasarkan ungkapan tersebut dapat dianalisis bahwa dalam kalimat tersebut terdapat nilai religius menepati janji. tanya Nisa. Hari ini ia mereka janjian mushallah kampus untuk bertemu. Ungkapan tersebuat termasuk salah satu nilai religius hubungan manusia dengan manusia aspek menepati janji karena pada kalimat tersebut menjelaskan bahwa sikap Nisa dan Rania dapat di jadikan contoh dalam kehidupan masyarakat karena mereka sama sama saling amanah dan menepati janji untuk bertemu di mushalla kampus, Hal ini sesuai dengan pendapat Wibowo, 2014:80).

\section{e. Aspek Memelihara Lingkungan Hidup}

Manusia yang memegang tugas kehalifahanya ditengah alam, sebagai subjek yang bertanggung jawab mengelola dan memelihara alam lingkunganya. Sebagai pengelola ia akan memanfaatkan alam untuk kesejahteraan hidupnya di dunia tanpa merusak da $\mathrm{n}$ membinasakan (Khozin, 2013:114). Manusia dengan alam sangatlah berkaitan satu sama lain, maka manusia harus menjaga dan memelihara alam dengan baik. ungkapan yang terdapan dalam aspek memelihara lingkungan hidup terdapat 1 ungkapan sebagai berikut.

Kutipan 10

"Jalan raya yang dulu ramai kini sepi dengan asap hitam di beberapa titik. Toko-toko ancur dengan pecahan kaca di mana-mana. Barang-barang di dalamnya berserakan, habis dijarah orang yang tidak berprikemanusiaan. Perkantoran juga mengalami nasib yang sama. Porakporanda. Bagai kota mati. Sedikit sekali tanda-tanda kehidupan. Semangat Hanif bergelora. Ia siap berjihad untuk negaranya. Perkataan Fahri barusan terus bergema di pikiran. Saat ini hatinya fokus pada perjuangan. Tidak yang lain" (RLCSM, 2019:65).

Dalam ungkapan tersebut terdapat nilai religius hubungan manusia dengan manusia dalam aspek memelihara lingkungan hidup. Berdasarkan ungkapan tersebut dapat dianalisis bahwa dalam kalimat tersebut terdapat nilai religius Semangat Hanif bergelora. ia siap berjihad untuk negaranya. Perkataan Fahri barusan terus bergema di pikiran. Saat ini hatinya fokus pada perjuangan. Tidak yang lain. Kalimat tersebut termasuk dalam nilai religius hubungan manusia dengan alam aspek memelihara lingkungan hidup. Karena kalimat tersebut menjelaskan bahwa Hanif melindungi lingkungan hidupanya dengan berjihad di jalan Allah agar lingkunganya tidak hancur di tangan orang-orang yang tidak bertanggung jawab. Hal ini sesuai dengan pendapat Khozin (2013:141). 


\section{SIMPULAN}

Dalam novel Rania Lantuan

Cinta DI Sepertiga Malam karya Eria Chuzaimiah dan Nasrullah terdapat aspek nilai-nilai religius yang berkaitan dengan hubungan manusia dengan Allah, manusia dengan manusia, manusia dengan alam sebanyak 164, sebagai berikut.

1. Dalam novel Rania Lantunan Cinta DI Sepertiga Malam karya Eria Chuzaimiah dan Nasrullah aspek beriman kepada Allah digambarkan dari dialog para tokoh yang selalu mengucapkan hal-hal yang dianjurkan dalam agama. Ungkapan yang berkaitan dengan aspek beriman kepada Allah terdapat 36 ungapan.

2. Dalam novel Rania Lantunan Cinta DI Sepertiga Malam karya Eria Chuzamiah dan Nasrullah, aspek beribadah kepada-Nya terlihat dari kegiatan yang dilakukan para tokoh yang selalu melaksankan ibadah. Ungkapan yang berkaitan dengan aspek beribadah kepada-Nya terdapat 44 ungkapan.

3. Dalam novel Rania Lantunan Cinta DI Sepertiga Malam karya Erina Chuzaimiah dan Nasrullah, aspek mensyukuri Nikmat-Nya terlihat dari kegiatan para tokoh yang tidak luput dari rasa syukur. Ungkapan yang berkaitan dengan aspek mensukuri nikmat-Nya terdapat 49 ungkapan.

4. Dalam novel Rania Lantunan Cinta DI Sepertiga Malam karya Erina Chuzaimiah dan Nasrullah Aspek bersabar menerima cobaan-Nya terlihat dari para tokoh yang selalu bersabar dalam menghadapi cobaan yang diberikan Allah. Ungkapan yang berkaitan dengan aspek bersabar menghadapi cobaan-Nya terdapat satu ungkapan.

5. Dalam novel Rania Lantunan Cinta DI Sepertiga Malam karya Erina
Chuzaimiah dan Nasrullah Aspek memohon ampun terlihat dari kegiatan para tokoh memohon ampun kepada Allah atas kesalahan atau dosa-dosa yang ia perbuat semasa hidupnya. Ungkapan yang berkaitan dengan aspek memohon ampun terdapat sembilan ungkapan.

6. Dalam novel Rania Lantunan Cinta DI Sepertiga Malam karya Erina Chuzaimiah dan Nasrullah, aspek adil terlihat dari dialog para tokoh yang tidak memandang seseorang dari dari latar belakangnya, adil dalam membagi tugas walau sesibuk apapun Ungkapan yang berkaitan dengan aspek adil dalam terdapat satu ungkapan.

7. Dalam novel Rania Lantunan Cinta DI Sepertiga Malam karya Erina Chuzaimiah dan Nasrullah, aspek tolong menolong terlihat dari dialog para tokoh dalam novel tersebut yang selalu tolong menolong, memberikan bantuan kepada orang lain yang sedang membutuhkan. Ungkapan yang berkaitan dengan aspek tolong terdapat sepuluh ungkapan.

8. Dalam novel Rania Lantunan Cinta DI Sepertiga Malam karya Erina Chuzaimiah dan Nasrullah, aspek pemaaf terlihat dari dialog para tokoh. Ungkapan yang berkaitan dengan aspek pemaaf terdapat delapan ungkapan.

9. Dalam novel Rania Lantunan Cinta DI Sepertiga Malam karya Erina Chuzaimiah dan Nasrullah, aspek menepati janji terlihat dari kegiatan yang dilakukan para tokoh. Tokohtokoh dalam novel tersebut bertanggung jawan dengan janjijanjinya walaupun sesibuk apapun kegiatan yang mereka kejakan. Ungkapan yang berkaitan dengan aspek menepati janji terdapat lima ungkapan. 
10. Dalam novel Rania Lantunan Cinta DI Sepertiga Malam karya Erina Chuzaimiah dan Nasrullah, aspek memelihara lingkungan hidup terlihat dari kegiatan para tokoh yang melindungi lingkunganya dan memperbaiki lingkunganya yang hancur dengan berbagai cara. Ungkapan yang berkaitan dengan aspek memelihara lingkungan hidup terdapat satu ungkapan.

Berdasarkan sepuluh aspek tersebut, dapat disimpulkan bahwa dari tiga jenis nilai religius yang dianalisis, nilai religius yang paling dominan yaitu nilai religius hubungan manusia dengan Allah terdapat 139 ungkapan dari lima aspek; selanjutnya nilai religius yang cukup dominan yaitu nilai religius hubungan manusia dengan manusia terdapat 24 ungkapan dari empat aspek; kemudian nilai religius yang paling sedikit adalah nilai religius hubungan manusia dengan alam hanya terdapat satu ungkapan dari satu aspek.

\section{DAFTAR PUSTAKA}

Danim, Sudarwan. (2002). Menjadi Penelitian Kualitatif. Bandung: CV Pustaka Setia.

Khozin. (2013). Khazanah Pendidikan Agama Islam. Bandung: PT Remaja Rosdakarya.

Kosasih, E. (2008). Apresiasi Sastra Indonesia. Jakarta: Nobel Edumedia.

Muhammad. (2011). Metode Penelitian Bahasa. Jogjakarta: Ar-Ruz Media.

Nasrullah dan Mia Chuz. (2019). Rania Lantunan Cinta Di Sepertiga Malam. Cirebon: KMO Indonesia.

Rokhmansyah, Alfian. (2014). Studi dan Pengkajian Sastra. Yogyakarta: Pustaka Pelajar.
Siswantoro, (2010). Metode Penelitian Sastra. Yogyakarta: Pustaka Pelajar.

Sugiyono, (2007). Metode Penelitian Pendidikan. Bandung: Alfabeta

Sugiyono. (2016). Metode Penelitian Kuantitatif, Kualitatif, dan $R \& D$. Bandung: Alfabeta.

Wibowo, Agus. (2014). Pendidikan Karakter Di Perguruan Tinggi. Yogyakarta: Pustaka Belajar. 